\title{
Evaluation of the resistance of CAC and BFSC mortars to biodegradation: laboratory test approach
}

\author{
Amr Aboulela ${ }^{1,2^{*}}$, Matthieu Peyre-Lavigne ${ }^{2}$, Cédric Patapy $^{1}$ and Alexandra Bertron ${ }^{1}$ \\ ${ }^{1}$ LMDC, Université de Toulouse, UPS, INSA, Toulouse, France \\ ${ }^{2}$ LISBP, Université de Toulouse, CNRS, INRA, INSA, Toulouse, France
}

\begin{abstract}
Biodeterioration of cementitious materials in sewer networks is a major concern for health and economic reasons. Essentially, it is due to the biological oxidation of $\mathrm{H}_{2} \mathrm{~S}$ into $\mathrm{H}_{2} \mathrm{SO}_{4}$ leading to a local progressive dissolution of the cementitious matrix and the precipitation of expansive products likely to provoke cracks. However, it is widely known that CAC has a better performance in such environments but the mechanisms are not very well understood. Nevertheless, previous studies focused mainly on measuring the mass loss of the specimens accompanied with little information on the chemical alteration of the cementitious matrix. This study aims to compare the performance of CAC and BFSC mortars in sewer conditions using laboratory test (BAC-test). Leaching kinetics were evaluated by concentrations measurements of cementitious cations in the leached solutions and of sulphate production by the microorganisms. Moreover, SEM observations coupled with EDS analyses allowed the identification of the chemical alteration of the cementitious matrix.
\end{abstract}

\section{Introduction}

Around $10 \%$ of sewer pipe failures were estimated to be due to microbial induced concrete corrosion (MICC) [1]. This phenomenon causes severe deterioration of the cementitious materials employed in sewer environments. Concrete sewer systems are composed of a lower liquid part and an upper aerial part (Figure 1). In the liquid part anaerobic sulphate reducing microorganisms (SRM) develop and reduce sulphate $\left(\mathrm{SO}_{4}{ }^{2-}\right)$ in the wastewater stream to produce hydrogen sulphide $\left(\mathrm{H}_{2} \mathrm{~S}\right)$. In the aerial part $\mathrm{H}_{2} \mathrm{~S}$ condensates on the concrete surface resulting in a progressive decrease in $\mathrm{pH}$, from 12 to around 9 in a first abiotic stage, leading to the development of aerobic sulphur oxidising microorganisms (SOM) $[2,3]$. Then, the dissociation of $\mathrm{H}_{2} \mathrm{~S}-$ due to the high relative humidity - produces sulphide ions which are oxidised into several sulphur species via several bio-chemical reactions. Sulphuric acid $\left(\mathrm{H}_{2} \mathrm{SO}_{4}\right)$ is produced as the final product of the oxidising chain reactions of these sulphur species transformations. The $\mathrm{H}_{2} \mathrm{SO}_{4}$ - produced by microorganisms on the material's surface and possibly inside the cementitious matrix [4] - is at the origin of a severe attack on the cementitious material. The deterioration phenomenon is essentially due to the dissolution of the cementitious phases and to the secondary precipitation of expansive products, such as gypsum and/or ettringite.

In sewer environments, the higher resistance of calcium aluminate cement (CAC) compared to ordinary Portland cement (OPC) is widely recognised [5-11]. Thus, this study aims to compare the performance of
CAC and blast furnace slag cement (BFSC) in a laboratory test reproducing sewer conditions.

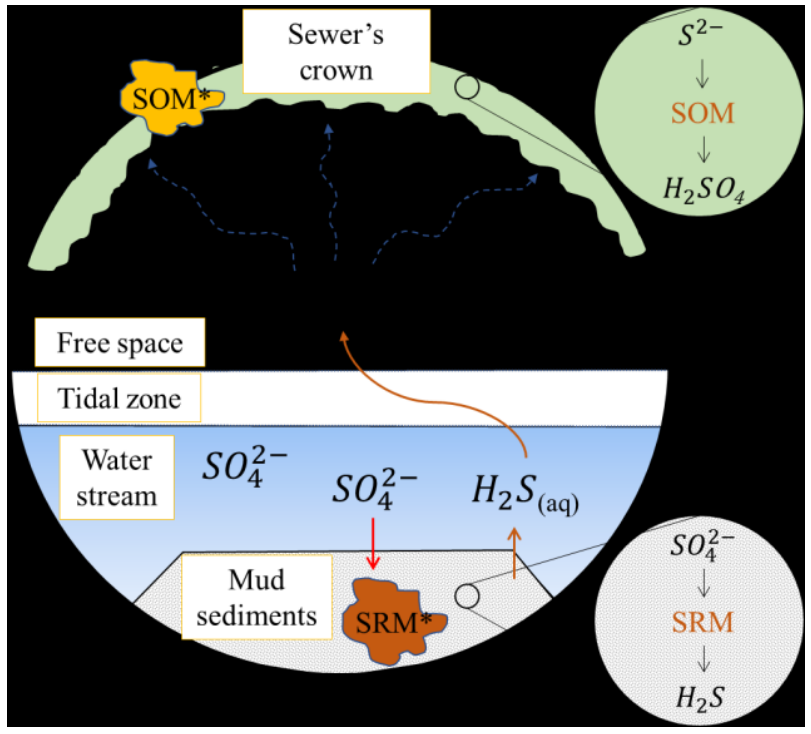

Figure 1. The sulphur cycle in the sewer system. *SRM: sulphate reducing microorganisms; *SOM: sulphur oxidising microorganisms

\section{Materials and Methods}

\subsection{Cementitious mortars}

The study was conducted on mortar specimens made of:

- A blast furnace slag cement containing $50 \%$ of slag, noted BFSC,

\footnotetext{
Corresponding author: bertron@insa-toulouse.fr
} 
Table 1. Chemical composition of CAC and BFSC binders

\begin{tabular}{|c|c|c|c|c|c|c|c|c|c|c|}
\hline Oxide & t.\%) & $\mathrm{CaO}$ & $\mathrm{SiO}_{2}$ & $\mathrm{Al}_{2} \mathrm{O}_{3}$ & $\mathrm{Fe}_{2} \mathrm{O}_{3}$ & MgO & $\mathrm{TiO}_{2}$ & $\mathbf{K}_{2} \mathrm{O}$ & $\mathrm{SO}_{3}$ & $\begin{array}{l}\text { Other } \\
\text { oxides }\end{array}$ \\
\hline \multicolumn{2}{|c|}{ CAC } & 37.9 & 5.1 & 52.1 & 1.6 & 0.3 & 2.1 & 0.4 & $<0.05$ & 0.5 \\
\hline \multirow{2}{*}{ BFSC } & $\mathrm{PC}$ & 68.2 & 22.7 & 2.5 & 0.2 & 0.5 & 0.1 & 0.5 & 2.3 & 3.0 \\
\hline & Slag & 43.3 & 37.1 & 11.1 & 0.6 & 6.5 & 0.5 & 0.2 & 0.2 & 0.5 \\
\hline
\end{tabular}

- A calcium aluminate cement containing around $50 \%$ of alumina, noted CAC.

The chemical composition of the cements is presented in Table 1. The preparation of the specimens was done according to the French Standard NF EN 1961. $450 \mathrm{~g}$ of cement and $1350 \mathrm{~g}$ of standardized silica sand mixed with $225 \mathrm{~g}$ of water then vibrated from 1 to 2 mins until the disappearing of air bubbles rising to the surface. The water to cement ratio was 0.5 .

BFSC mortars were kept in sealed bags at $20^{\circ} \mathrm{C}$ and $\mathrm{CAC}$ mortars were cured for $2 \mathrm{~h}$ at $70^{\circ} \mathrm{C}$ with $100 \% \mathrm{RH}$ to accelerate the conversion process of the hydration products and to obtain stable phases such as $\mathrm{C}_{3} \mathrm{AH}_{6}$. Afterwards, CAC mortars were cured for $22 \mathrm{~h}$ at $20^{\circ} \mathrm{C}$ with $100 \% \mathrm{RH}$ and finally put in sealed bags at $20^{\circ} \mathrm{C}$.

\subsection{Durability test: BAC-test}

The BAC-test, for Biogenic Acid Concrete was developed at INSA Toulouse to assess the resistance of cementitious based materials to biogenic acid attack. Figure 2 shows the BAC-test experimental pilot design $[6,7]$. The test pilot was made up from a 200-liter tank (1), connected to the test apparatus by plastic tubes used to transport the solution from the tank via flow pumps (2) and drop it on the top of the specimens (3) which were covered with the inoculum obtained from an activated sludge. The specimens were laid on inclined supports with a low slope to optimize the retention time of the solution in contact with the cementitious material [8].

The feeding solution was composed of tetrathionate $\left(\mathrm{K}_{2} \mathrm{~S}_{4} \mathrm{O}_{6}\right)$ as a soluble reduced sulphur source and other nutrients, such as nitrogen, phosphorus, iron, chloride and oligo-elements, required for microorganisms' growth, dissolved in deionized water [6]. Downstream of the specimens the leaching solutions were punctually collected (4) and filtered at $0.45 \mu \mathrm{m}$ to eliminate all microorganisms that could have fallen into the collecting tubes and to stop any further biochemical reaction in the collection tubes. The liquid samples were, then, stored in at $4{ }^{\circ} \mathrm{C}$ after measuring the $\mathrm{pH}$. These samples were used to measure the concentration of $\mathrm{Ca}^{2+}, \mathrm{Al}^{3+}$ and $\mathrm{SO}_{4}{ }^{2-}$ in the leaching solution. At the end of the test, the cement paste specimens were collected for microstructural and chemical analyses and degraded depth measurements. The representativeness and reproducibility of the test method were demonstrated in previous campaigns [6-8].
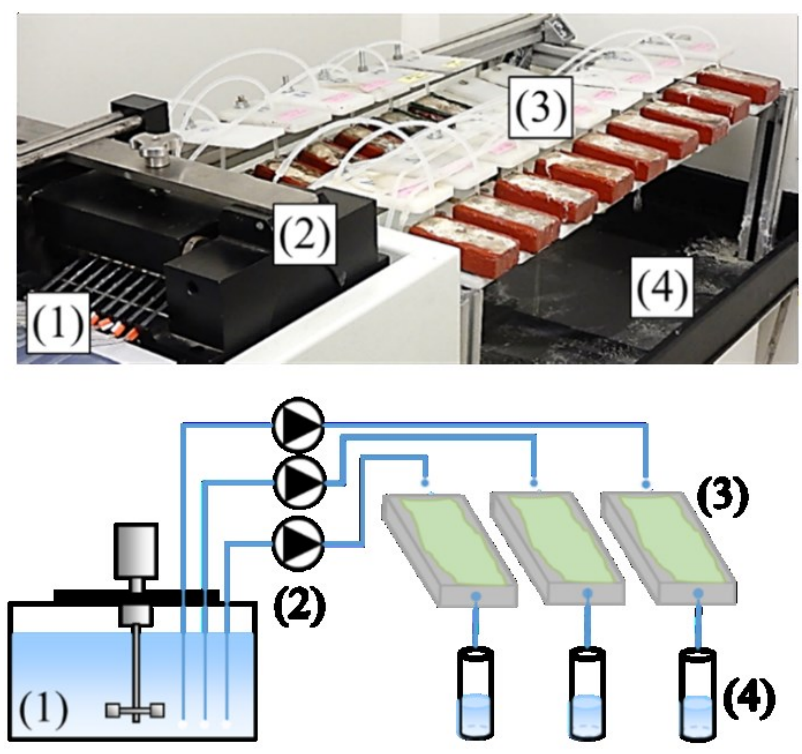

Figure 2. The BAC-test experimental pilot and a schematic layout of the test

\subsection{Methods}

\subsubsection{Analyses of the aggressive solutions during the exposure}

Leaching solution samples were filtered at $0.45 \mu \mathrm{m}$ and then acidified using $\mathrm{HNO}_{3}$ Plasma-Pure at $2 \%$ of the liquid volume. The concentrations of $\mathrm{Ca}$ and $\mathrm{Al}$ in the solutions were measured by ICP-OES (Optima 7000 DV machine).

The same samples analysed by ICP were, then, diluted with a factor of 10 to reduce the peak of $\mathrm{HNO}_{3}$ and to be able to distinguish the sulphate peak. The concentrations of sulphate were measured using Dionex ICS-39 with an AS-11 HC column and $\mathrm{KOH}$ as eluent.

\subsubsection{Analyses of the degraded materials}

Flat sections were sawn and put into a resin - Mecapex MA2+ with the appropriate catalyser - before being polished and coated with a carbon film. These sections were used for microstructural observations and chemical analyses using a scanning electron microscope (JEOL JSM-6380LV with accelerating voltage $15 \mathrm{kV}$ ) in back scatter electron (BSE) mode and were completed with elemental mapping analyses using energy dispersive spectroscopy (Rontec XFLASH 3001). 


\section{Results and discussion}

\subsection{Bacterial activity and sulphate production}

Figure 3 shows the $\mathrm{pH}$ evolution of the leaching solutions for the specimens subjected to biogenic sulphuric acid for 52 days. For the first 3 days, the $\mathrm{pH}$ increased for both materials because of the leaching of the very outer layer of cement pastes once in contact with the solution. During these 3 days, microorganisms' selection was being done as SOM have found a sulphur substrate $\left(\mathrm{K}_{2} \mathrm{~S}_{4} \mathrm{O}_{6}\right)$ which allowed them to develop and to create the biofilm.

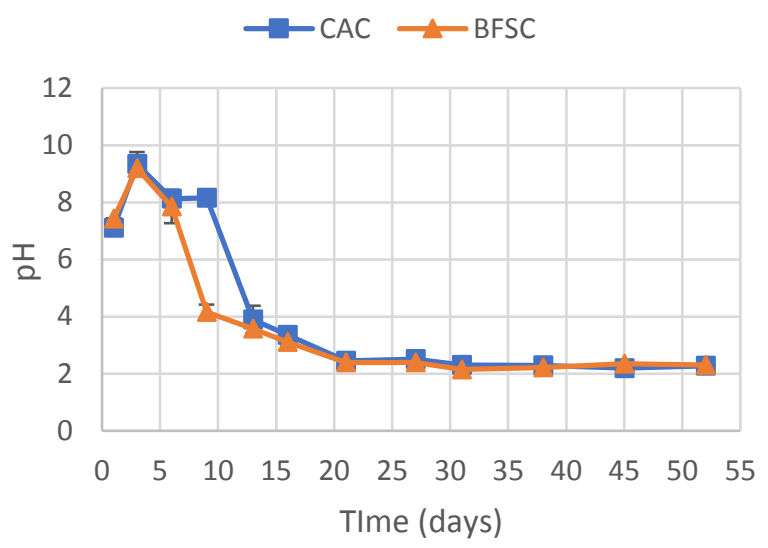

Figure 3. $\mathrm{pH}$ evolution of $\mathrm{CAC}$ and $\mathrm{BFSC}$ leaching solutions exposed to BAC-test

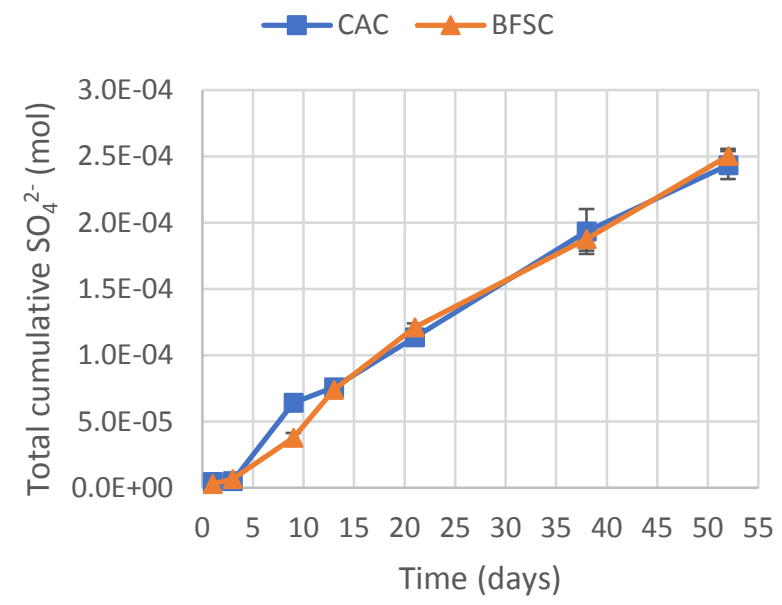

Figure 4. Total cumulative $\mathrm{SO}_{4}{ }^{2-}$ produced by microorganisms on top of CAC and BFSC materials

The first 3 days marked the development of the neutrophilic sulphur oxidizing bacteria (NSOM). The activity of these microorganisms was limited by the high $\mathrm{pH}$ and therefore, the amount of produced sulphate was relatively low (Figure 4), leading to a slow progressive decrease of the $\mathrm{pH}$. However, CAC showed a slightly higher buffer effect compared to BFSC as the $\mathrm{pH}$ took several additional days to reach acidic values. Nevertheless, starting from 21 days, the $\mathrm{pH}$ of both materials stabilised around 2.5 until the end of the test, in accordance with other experimental campaigns [8, 12], showing the high aggressiveness of the chemical conditions set by the BAC test.

Nonetheless, quantification of sulphate in the leaching solution showed that the amount of sulphate produced by microorganisms on both materials' surface was very similar, as shown on Figure 4.

\subsection{Cementitious cations leaching}

Figure 5 shows a significant difference in the amount of leached calcium between CAC and BFSC, although, the same amount of sulphate was produced on both materials' surface (Figure 4). The total cumulative leached $\mathrm{Ca}^{2+}$ per initial total $\mathrm{Ca}^{2+}$ in the BFSC binder was found to be two times higher compared to CAC. The same behaviour was observed on $\mathrm{Al}^{3+}$ leaching with $0.002 \mathrm{molCa} / \mathrm{molCa}$ and $0.008 \mathrm{molAl} / \mathrm{molAl}$ for $\mathrm{CAC}$ and BFSC respectively.

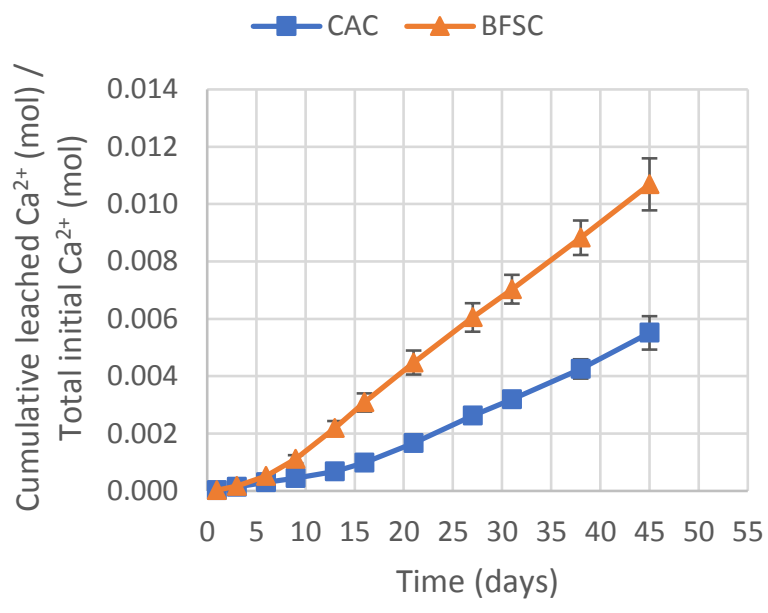

Figure 5. Cumulative leached $\mathrm{Ca}^{2+}$ by initial binder content during the exposition of CAC and BFSC to the BAC-test

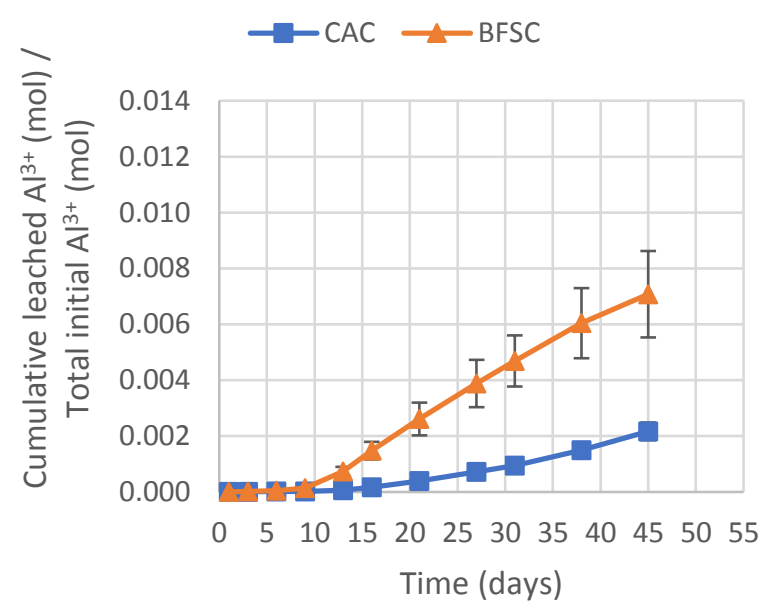

Figure 6. Cumulative leached $\mathrm{Al}^{3+}$ by initial binder content during the exposition of $\mathrm{CAC}$ and BFSC to the BAC-test

The different behaviour between CAC and BFSC could be explained by the different chemistry of the cement and the chemical stability of their phases. For 
instance, katoite $\left(\mathrm{C}_{3} \mathrm{AH}_{6}\right)$ and gibbsite $\left(\mathrm{AH}_{3}\right)$ are the main phases of CAC while $\mathrm{C}-(\mathrm{A})-\mathrm{S}-\mathrm{H}$ is the dominant phase - along with AFm/AFt phases - of BFSC. On one hand, AH3 is known for its high chemical stability in acidic environments (down to $\mathrm{pH} \mathrm{3-4),} \mathrm{moreover,} \mathrm{the}$ dissolution of $\mathrm{C} 3 \mathrm{AH} 6$ results in the production of additional $\mathrm{AH}_{3}$ inside the cementitious matrix.

Also, some authors reported the capacity of the aluminium gel to create a physical barrier against the sulphur penetration $[13,14]$. However, the aggressive exposure conditions of the BAC-test induced such acid flow on the material's surface that the impact of the gel physical barrier properties was lowered [15]. Sulphur may also have penetrated the material before the formation of the surface gel as several studies showed ettringite precipitations near the degradation front, under the alumina gel $[7,16,17]$.
On the other hand, C-(A)-S-H, AFm and AFt phases are unstable in acidic medium, which might result in the total decalcification of C-(A)-S-H [18], leaving a very porous $\mathrm{Si}-\mathrm{Al}$ gel with no cohesive properties. Furthermore, the dissolution of AFm/AFt phases could act as an internal source of $\mathrm{SO}_{4}{ }^{2-}$, which might accelerate the degradation.

\subsection{Degradation mechanisms}

At the end of the test, the mortars samples were collected for chemical analyses. Backscattered electron images from SEM observations and chemical elemental $(\mathrm{Ca}, \mathrm{Si}$, $\mathrm{Al}$ and $\mathrm{S}$ ) maps of polished sections obtained for $\mathrm{CAC}$ and BFSC are shown in Table 2.

Table 2. Chemical elemental mapping of CAC and BFSC samples after 52 days of exposure to biogenic acid using the BAC-test

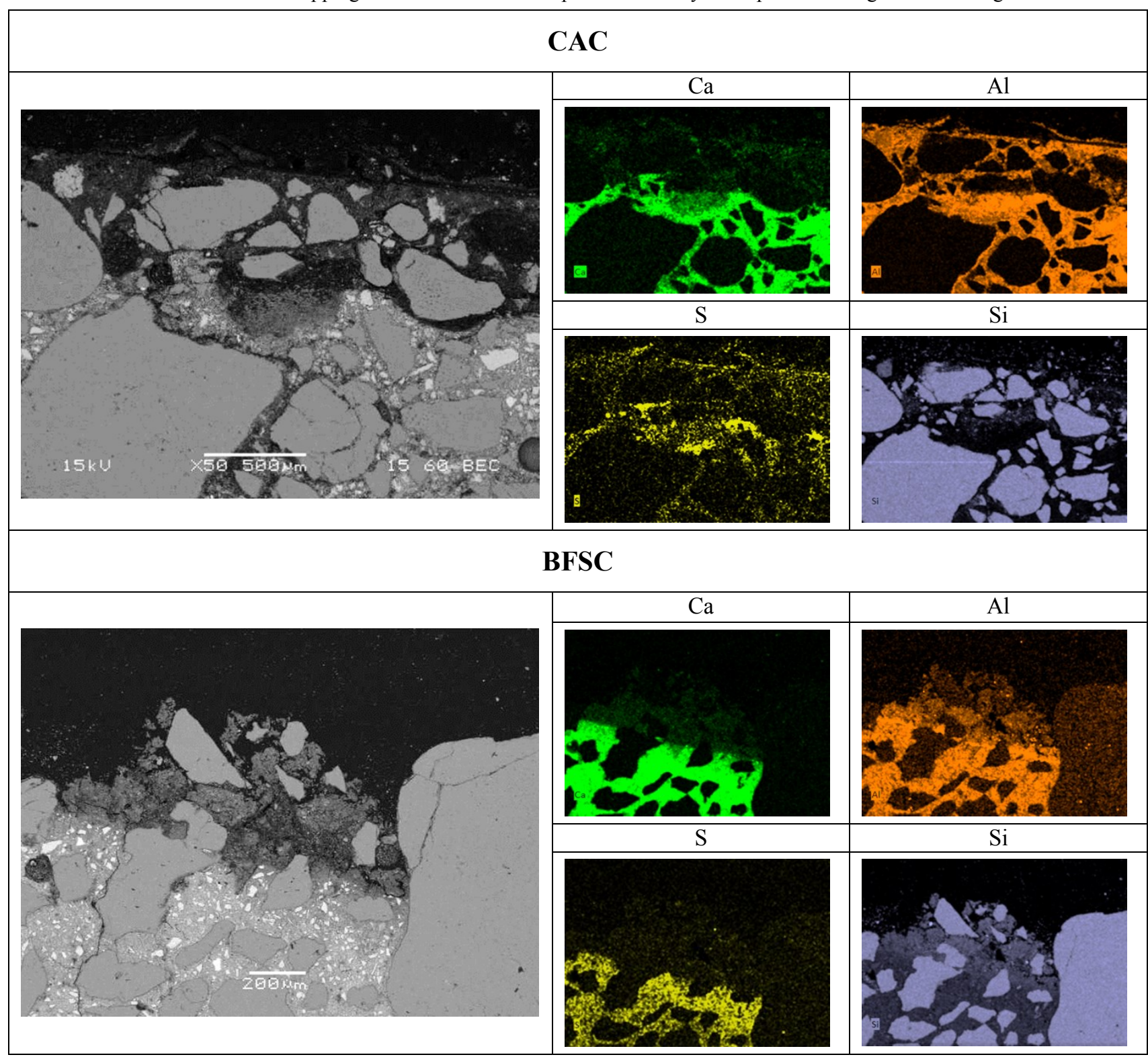




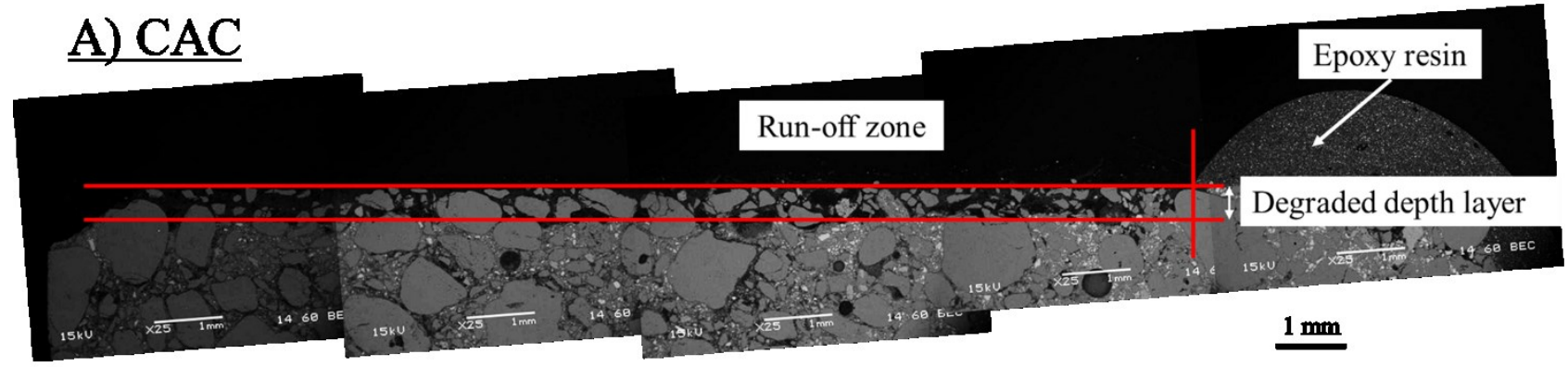

\section{B) BFSC}

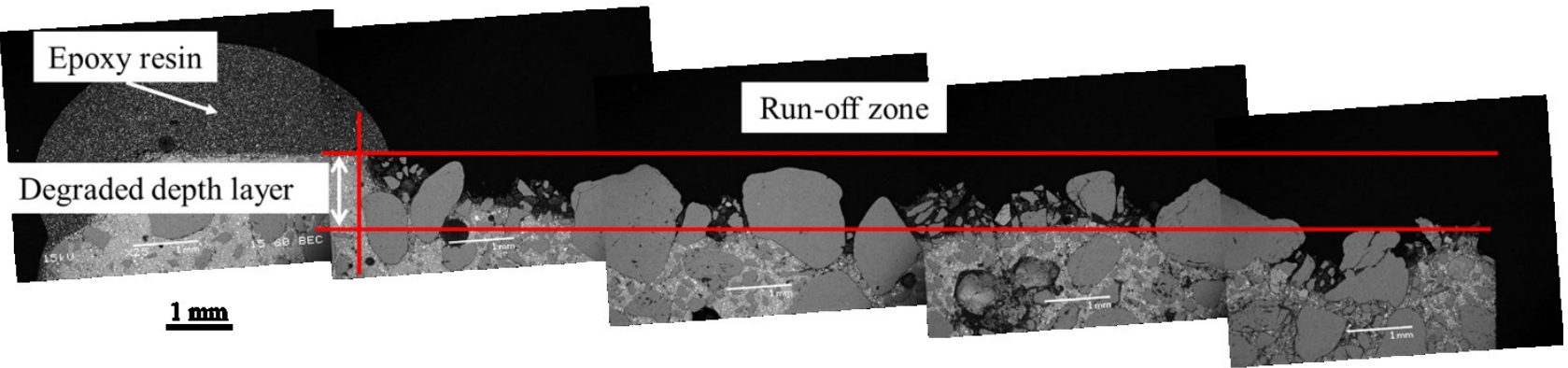

Figure 7. SEM observations (BSE images) of deteriorated mortars sample (A) CAC and (B) BFSC after 52 days of exposure to biogenic acid using the BAC-test

Regarding the CAC sample, a relatively homogeneous dark grey zone was observed at the surface which corresponded to a more porous and highly decalcified layer of the specimen. The average thickness of the decalcified layer was approximately $500 \mu \mathrm{m}$. However, as this altered layer was enriched in $\mathrm{Al}$, previous works demonstrated that $\mathrm{Al}(\mathrm{OH})_{3}$ was the main mineral in this zone [7-10]. Also, while CAC mortars did not initially contain any $\mathrm{S}$, the degradation front between the altered layer and the sound zone exhibited local enrichments of $\mathrm{S}$, which confirmed the diffusion of sulphur species inward the cementitious specimen.

However, the nature of the S-based minerals was not determined in this study but it is likely to be mainly gypsum as reported in [7, 11]. The silicate sand did not suffer any degradation. Nonetheless, some aggregates got detached from the specimen due to the dissolution of the binder.

Regarding the BFSC sample, three zones were identified parallel to the surface. The outer zone was completely dissolved due to the high aggressiveness of the acid attack. Also, the silica sand got detached from this zone and felt apart. The totally dissolved zone had an average thickness of $600 \mu \mathrm{m}$. The second zone called degraded zone - had a dark grey shade and corresponded to the highly deteriorated zone at the surface of the specimen. The thickness of this strongly deteriorated zone was estimated at $500 \mu \mathrm{m}$. Finally, the inner zone had a similar grey shade as the core of the specimen and corresponded to the sound zone. The degraded zone was highly decalcified and was mainly composed of $\mathrm{Si}$ and $\mathrm{Al}$. It might be due to the decalcification of C-(A)-S-H, leading to the precipitation of an amorphous Al-Si gel on the surface. Moreover, S was detected at the degradation front between the degraded zone and the unaltered zone, which could be used as an indirect validation of the diffusion of sulphate - produced by SOM - to deeper zones. Lastly, the silica aggregates did not suffer any chemical alteration but still got detached from the specimen as for the CAC specimen.

Figure 7 presents the profiles of the cross-sections of CAC and BFSC obtained by SEM. An epoxy resin - on the right and left sides for CAC and BFSC respectively was used to identify the initial surface of the material which served as a reference for the degraded depths estimations.

The total degraded depth was measured using image analyses techniques and was obtained by averaging the surface of the dissolved and the degraded zones over the initial sound zone surface. The total degraded depths for CAC and BFSC were estimated at $500 \mu \mathrm{m}$ and $1100 \mu \mathrm{m}$ respectively.

\section{Conclusion}

In this study, CAC and BFSC mortars were exposed to an accelerated biodegradation laboratory test (BAC-test) for 52 days.

The main results highlighted the better performance of CAC over BFSC. The chemical and mineralogical compositions of the binders were key players facing the biogenic sulfuric acid attack. The better thermodynamic stability of $\mathrm{C}_{3} \mathrm{AH}_{6}$ and $\mathrm{AH}_{3}$ compared to $\mathrm{C}-(\mathrm{A})-\mathrm{S}-\mathrm{H}$, AFm and AFt phases could explain the better resistance of calcium aluminate based materials. Furthermore, the degradation of $\mathrm{C}_{3} \mathrm{AH}_{6}$ by sulphuric acid led to the precipitation of additional $\mathrm{AH}_{3}$ which has a high chemical stability in acidic environments (down to $\mathrm{pH} 3$ 4). However, the severe conditions of the BAC-test significantly reduced the importance of the barrier effect 
of the gel as the enrichment of sulphur at the degradation front confirmed the diffusion of sulphur species inside the cementitious matrix despite the presence of the alumina gel on the surface. These results came in accordance with the literature [15]. In summary, the degraded zone was less deteriorated in the case of CAC matrix than in the case of BFSC one.

\section{References}

[1] W. Kaempfer and M. Berndt, "Durability of Building Materials and Components 8: Service Life and Durability of Materials and Components." Durability of Building Materials \& Components 8, NRC Research Press (1999)

[2] C.D. Parker, "Species of Sulphur Bacteria Associated with the Corrosion of Concrete" 159, 439-40 (1947)

[3] C.D. Parker, "Mechanics of Corrosion of Concrete Sewers by Hydrogen Sulfide" Sewage and Industrial Wastes 23 (12): 1477-85 (1951)

[4] C. Grengg, F. Mittermayr, G. Koraimann, F. Konrad, M. Szabó, A. Demeny, M. Dietzel, "The decisive role of acidophilic bacteria in concrete sewer networks: A new model for fast progressing microbial concrete corrosion" Cement and Concrete Research, 101, 93-101 (2017)

[5] J. Herisson, M. Guéguen-Minerbe, E.D. Van Hullebusch, T. Chaussadent, "Influence of the binder on the behaviour of mortars exposed to H2S in sewer networks: a long-term durability study", Mater Struct $\mathbf{5 0}$ (8) 1-18 (2017).

[6] M. Peyre Lavigne, A. Bertron, L. Auer, G. Hernandez-Raquet, J.N. Foussard, G. Escadeillas, A. Cockx, E. Paul, "An Innovative Approach to Reproduce the Biodeterioration of Industrial Cementitious Products in a Sewer Environment. Part I: Test Design." Cement and Concrete Research 73, 246-56 (2015)

[7] M. Peyre Lavigne, A. Bertron, C. Botanch, L. Auer, G. Hernandez-Raquet, A. Cockx, J.N. Foussard, G. Escadeillas, E. Paul, "Innovative Approach to Simulating the Biodeterioration of Industrial Cementitious Products in Sewer Environment. Part II: Validation on CAC and BFSC Linings." Cement and Concrete Research 79, 409-18 (2016).

[8] M. Peyre Lavigne, A. Bertron, C. Patapy, X. Lefebvre, E. Paul, "Accelerated test design for biodeterioration of cementitious materials and products in sewer environments" Matériaux \& Techniques, 103 (2) (2015)
[9] C. Lors, J. Aube, R. Guyoneaud, F. Vandenbulcke, D. Damidot, "Biodeterioration of mortarts in sewers: relation with microbial diversity of biofilms", Microorganisms-Cementitious materials Interactions, 1, 143-152 (2018)

[10] J. Herisson, E.D. van Hullebusch, M. MolettaDenat, P. Taquet, T. Chaussadent, "Toward an accelerated biodeterioration test to understand the behavior of Portland and calcium aluminate cementitious materials in sewer networks", Int. Biodeterior. Biodegrad., 84, 236-243 (2013)

[11] A. Grandclerc, "Compréhension des mécanismes de biodétérioration des matériaux cimentaires dans les réseaux d'assainissement : étude expérimentale et modélisation", Université Paris-Est, Thesis (2017)

[12] A. Aboulela, M. Peyre Lavigne, A. Bertron, "Investigation of test methods to qualify cementitious materials subjected to biological attack in sewer conditions". In A. Bertron, H. Jonkers (ed.) Proceedings of RILEM TC 253-MCI Conference MicroorganismsCementitious Materials Interactions PRO123, RILEM Edition, Paris, 45-56 (2018).

[13] H. Fryda, F. Saucier, S. Lamberet, K. Scrivener, D. Guinot, "Durabilité des bétons d'aluminate de calcium (Calcium aluminate concrete durability)", La durabilité des bétons, 767-823 (2010)

[14] J. Herisson, M. Guéguen-Minerbe, E.D. van Hullebusch, T. Chaussadent, "Behaviour of different cementitious material formulations in sewer networks", Water Science and Technology, 69, 1502-1508 (2014)

[15] A. Buvignier "Étude et caractérisation du rôle de l'aluminium dans les interactions entre les biofilms et les matériaux cimentaires dans le cadre des réseaux d'assainissement", Université de Toulouse, Thesis (2018)

[16] S. Ehrich, L. Helard, R. Letourneux, J. Willocq, E. Bock, "Biogenic and Chemical Sulfuric Acid Corrosion of Mortars", Journal of Materials in Civil Engineering 11, 340-344 (1999)

[17] M.W. Kiliswa, "Composition and microstructure of concrete mixtures subjected to biogenic acid corrosion and their role in corrosion prediction of concrete outfall sewers" University of Cape Town, Thesis (2016)

[18] Anaïs Grandclerc, Patrick Dangla, Marielle Gueguen-Minerbe, Thierry Chaussadent, "Modelling of the sulfuric acid attack on different types of cementitious materials", Cement and Concrete Research, 105, 126133 (2018) 